\title{
Physiologically based limits to food consumption, and individual-based modeling of foraging and growth of larval fishes
}

\author{
Myron A. Peck*, Ute Daewel \\ Institute for Hydrobiology and Fisheries Science, University of Hamburg, Olbersweg 24, 22767 Hamburg, Germany
}

\begin{abstract}
Larval fish individual-based models (IBMs) that include foraging subroutines to depict prey encounter, capture and ingestion often include static parameters (e.g. a maximum feeding rate, $C_{\mathrm{MAX}}$ ) to prevent 'overfeeding' and unrealistically high growth rates. We formulated 2 physiologically based approaches to limit food consumption rate $(C)$ based on gut capacity and evacuation rate $(G E R)$ and feeding rate-dependent changes in assimilation efficiency $(A E)$. Parameterizations were based on data reported for a variety of marine and freshwater teleost larvae. The effects of the 3 approaches $\left(C_{\mathrm{MAX}}, G E R\right.$ and $\left.A E\right)$ on feeding and growth were compared in IBM simulations of $12 \mathrm{~mm}$ larval sprat Sprattus sprattus L. foraging within homogenous and patchy prey fields. Prey concentrations for maximum growth were between 5 and 10 copepodites $\mathrm{l}^{-1}$, similar to thresholds determined for successful foraging by larvae of other marine fish species in laboratory studies. The $A E$ limit allowed larvae to exploit prey patches (to consume prey at higher rates but at lower $A E \mathrm{~s}$ ). In simulations using prey concentrations observed in productive areas of the southern North Sea (e.g. 21.0 copepodites $~^{-1}$ ), larvae benefited little (benefited much) from adopting this patch feeding strategy when patch prey concentrations were $\leq 2$-fold ( $\geq 5$-fold) those outside of the patches. At $\leq 10$ copepodites $1^{-1}$, foraging model predictions of $C$ were close to limits imposed by $C_{\mathrm{MAX}}, G E R$ and $A E$ methods. In patches (20 to 40 copepodites $1^{-1}$ ), foraging model estimates of $C$ were 2 - to 4 -fold greater than the highest ( $A E$ based) limit. Physiological-based limits to $C$ are recommended for larval fish IBMs and will be necessary to adequately assess the impacts of prey patchiness on survival and growth of marine fish larvae.
\end{abstract}

KEY WORDS: Larval fish - Foraging - Prey patches - Individual-based models - Gut evacuation · Assimilation efficiency $\cdot$ Sprattus sprattus

\section{INTRODUCTION}

Individual-based models (IBMs) utilizing functions to depict foraging, metabolism and growth have been used to explore the impacts of extrinsic factors such as turbulence, light and prey concentration on the vital rates of larval marine fish (e.g. Letcher et al. 1996, Werner et al. 1996, Fiksen \& Folkvord 1999, Hinrichsen et al. 2002, Lough et al. 2005). However, simulating 'realistic' rates of food consumption $(C)$ by a modeled larva is somewhat of a Herculean task, since it is not a trivial matter to define what is 'realistic' for field larvae. Field estimates of $C$ for larval fish must often be based upon a number of assumptions regarding in situ prey fields (i.e. that the mean prey concentration calculated from net hauls adequately represents the prey field that individual larvae encounter) and/or aspects of larval physiology (i.e. that rates of digestion and gut evacuation are adequately known; Pepin \& Penney 2000). Rates of food consumption have been quantified in laboratory studies for the larvae of a variety of marine teleosts (e.g. see Houde 1989, Houde \& Zastrow 1993), but these rates do not always compare well with field estimates (MacKenzie et al. 1990).

Attempting to simulate the situation in the wild, larval fish $C$ within IBMs is influenced by an amalgam of variables including prey concentration, one of the main factors modulating contact rates of predators and 
prey. When prey concentrations are high, IBM estimates of $C$ can be unrealistically high and 'overfeeding' can lead to unrealistically high growth rates. This problem has been solved by ignoring overestimates of $C$ and defining growth limits $\left(G_{\mathrm{MAX}}\right)$ from age-length models (Hinrichsen et al. 2002, Bartsch \& Coombs 2004) or laboratory growth rates during ad libitum feeding (Fiksen \& Folkvord 1999). An upper limit to $C$ $\left(C_{\mathrm{MAX}}\right)$ has also been employed (Werner et al. 1996, U. Daewel et al. unpubl. data). These approaches $\left(G_{\mathrm{MAX}}\right.$ or $C_{\mathrm{MAX}}$ ) supersede foraging model predictions and are not mechanistic. Moreover, growth models of larval, juvenile and adult fish are often most sensitive to such parameters (e.g. Bartell et al. 1986, Hinrichsen et al. 2002, Maes et al. 2005, U. Daewel et al. unpubl. data).

The requirement of simulating 'realistic' $C$ in larval fish IBMs also makes it necessary to employ 'quasirealistic' prey fields. Typically, this has been accomplished by utilizing average values of species- and/or stage-specific zooplankton concentration (no. $\mathrm{m}^{-3}$ ) from in situ net sampling (e.g. Werner et al. 1996, Hinrichsen et al. 2002). These prey fields are likely adequate for projecting larval growth at relatively long time (several weeks) and large spatial scales (banks, shelves), but, at shorter time (days) and smaller spatial (frontal zones) scales, variability in prey fields may become an increasingly relevant factor affecting the vital rates of larval fish. Stochasticity in prey fields experienced, for example, by a larva foraging inside and outside of thin layers (e.g. Dekshenieks et al. 2001) or among prey patches at sub-meter scales (e.g. Owen 1989) was included in the seminal modeling work of Beyer \& Laurence (1980) and Laurence (1985). However, in the following decades, modeling efforts have rarely included stochasticity in prey fields (see Letcher et al. 1996). This is interesting in light of the advances made in video sampling systems (e.g. video plankton recorder and other optical packages) that now provide estimates of fine-scale prey distributions over large areas, such as across frontal zones (e.g. Broughton \& Lough 2006). Including prey field variability in models will undoubtedly become more relevant as researchers explore sources of variability in short-term larval growth rates (e.g. Lough et al. 2005, 2006). Furthermore, it has been argued that implementing stochasticity in foraging processes on both short and long time scales may be required to understand growth and recruitment variability (e.g. see Pitchford et al. 2005).

In the present modeling study, we (1) reviewed the available literature on larval feeding, gut evacuation and assimilation efficiency, (2) formulated interspecific, mechanistic limits to larval fish $C$ and (3) conducted a series of $8 \mathrm{~d}$ IBM simulations within homogeneous and patchy prey fields. Model runs employed a variety of prey (copepod) concentrations that had an abundance-at-size spectrum that was characteristic of the southern North Sea. Model simulations investigated how mechanistic feeding limits, as opposed to the prevalent approach of using nonmechanistic limits (e.g. a $C_{\mathrm{MAX}}$ parameter), influenced short-term projections of larval feeding and growth.

\section{MATERIALS AND METHODS}

IBM foraging and growth. The IBM used in this study is thoroughly described elsewhere (U. Daewel et al. unpubl. data). Model formulations and parameterizations were based on laboratory studies on larval Atlantic herring Clupea harengus L. and field data collected for larval sprat Sprattus sprattus L., and only the main features of the subroutines are presented here. Larval growth $(G$, in $\mu$ g dry mass per model time step) was calculated as the difference between net energy input and metabolic losses:

$$
G=C \times A E \times\left(1-R_{\mathrm{SDA}}\right)-R
$$

where consumed prey mass $(C, \mu g$ dry mass per model time step) was reduced by an assimilation efficiency $(A E)$ and metabolic losses $(R)$ that were divided into several subcomponents to account for standard $\left(R_{\mathrm{S}}\right)$, feeding (specific dynamic action, $\left.R_{\mathrm{SDA}}\right)$ and active $\left(R_{\mathrm{A}}\right)$ rates of energy loss. In Eq. (1), $R$ represented $R_{\mathrm{S}}$ when light was below a threshold for feeding, otherwise it represented $R_{\mathrm{A}}$. Effects of body mass (Kiørboe et al. 1987) and temperature (Almatar 1984) on $R$ were taken from work on larval herring.

The mass of prey consumed was calculated as a function of encounter rate $\left(N_{S L, i}\right)$, prey mass $\left(m_{i}\right)$, capture success $\left(C S_{S L, i}\right)$, handling time $\left(H T_{S L, i}\right)$ and the time interval $(\Delta t)$ (Letcher et al. 1996):

$$
C=\frac{\sum_{i} m_{i} N_{S L, i} C S_{S L, i}}{1+\sum_{i} N_{S L, i} H T_{S L, i}} \Delta t
$$

where $S L$ is larval fish standard length and $i$ refers to a specific prey class. An optimal foraging approach was used in which different prey types were ranked according to their mass, capture success and handling time. Prey items were included in the diet sequentially on the basis of rank until profitability decreased (see Letcher et al. 1996 and references therein). The capture success was calculated as a function of prey length and larval length based on the attack success function of Munk (1992) for larval Atlantic herring parameterized using field data on larval sprat gut contents (Dickmann 2006). The handling time was calculated following an empirically derived equation from Walton et al. (1992). The model also incorporated light level and turbulence to modify prey capture success (see U. Daewel 
et al. unpubl. data), but these factors were not examined in the present study.

Assimilation efficiency was given by:

$$
A E_{\text {std }}=0.7\left(1-0.3 \mathrm{e}^{-0.003\left(M_{\mathrm{D}}-M_{\mathrm{DMIN}}\right)}\right)
$$

where $M_{\mathrm{D}}$ was larval dry mass $(\mu \mathrm{g})$ and $M_{\mathrm{DMIN}}$ was larval dry mass at first feeding $(\mu \mathrm{g})$. The functional form of Eq. (3) was based upon measurements made on larvae of different marine fish species, including summer flounder Paralichthys dentatus, spot Leiostomus xanthurus and American sole Achirus fasciatus (Buckley \& Dillman 1982, Govoni et al. 1982, Houde \& Schekter 1983).

In the present study, the output from Eq. (2) is referred to as 'foraging model estimates of $C$ '. In the next sections, we describe 3 different approaches to place limits on foraging model estimates of the food consumed and assimilated during each model time step.

Case $1-\boldsymbol{C}_{\text {MAX }}$ : The first approach used to prevent overfeeding was to employ a $C_{\text {MAX }}$ function:

$$
C_{\mathrm{MAX}}=1.315 M_{\mathrm{D}}^{0.83} 2.872^{\left[\frac{(T-15)}{10}\right]}
$$

that yielded larval dry mass $\left(M_{\mathrm{D}}, \mu \mathrm{g}\right)$ - and temperature ( $T$ )-specific limits to $C$ that balanced in situ estimates of temperature-specific larval sprat growth in the North and Baltic Seas (Munk 1993, Ré \& Gonçalves 1993, Huwer 2004, Baumann et al. 2006). Eq. (4) was employed when foraging model estimates of $C$ were $>C_{\text {MAX }}$. In this case, the standard formulation of $A E$ (Eq. 3) was used, and the product of Eqs. (3) and (4) provided the non-mechanistic limit to assimilated $C$.

Case 2-gut evacuation rates: A physiologically based approach to limit $C$ was based upon gut evacuation rate $(G E R)$ and knowledge of the maximum gut fullness. This method has recently been used in an IBM for Georges Bank larval cod Gadus morhua (Lough et al. 2005). In that study, GER was assumed to be linear and to take approximately $4 \mathrm{~h}$. A linear GER model was able to explain the rate of decrease in gut contents observed during repeated field samplings in darkness for larvae and young juveniles of 8 fish species (Bochdansky \& Deibel 2001, Bochdansky et al. 2006). The rate of decrease in gut contents of larval sprat in the field also appeared to be linear, with a mean $( \pm S E)$ slope $(G E R)$ of $0.46(0.08) \mathrm{h}^{-1}$ (M. A. Peck unpubl. data). This rate implies complete gut emptying within $\sim 2 \mathrm{~h}$ and agrees well with that calculated for larval Atlantic herring by Pedersen (1984) and rates calculated for similar-sized larvae of other species at similar temperatures (Table 1).

The effect of body size and temperature $(T)$ on GER was based upon an analysis of data presented within 27 studies on 22 fish species (Table 1 ). The effect of $T$ on GER was described by a $Q_{10}$ of $\sim 2.4$ for Atlantic herring larvae feeding upon Balanus nauplii (Blaxter 1962), and the same value was found for northern pipefish Syngnathus fuscus feeding upon wild zooplankton (Ryer \& Boehlert 1983). Boehlert \& Yoklavich (1983) measured GERs of 0.0190, 0.0293 and $0.0385 \mathrm{~h}^{-1}$ at 7,12 and $18^{\circ} \mathrm{C}\left(Q_{10}=1.88\right)$ in juvenile (69 to $82 \mathrm{~mm}$ $S L)$ black rockfish Sebastes melanops. Temperaturenormalized $\left(12^{\circ} \mathrm{C}, Q_{10}=2.0\right)$, log-transformed $G E R$ s of 16 species (studies for which both fish size and water temperature were provided) decreased with log body size in a linear fashion (Fig. 1A). Based upon the literature review, an equation relating GER to body size and temperature was formulated:

$$
G E R=1.79 S L^{-0.83} Q_{10}\left[\frac{(T-12)}{10}\right]
$$

where the $Q_{10}$ parameter was set to 2.0 .

A review of the literature also suggested that a 2- to 5-fold increase in GER occurred when measurements made during feeding were compared to those made after the cessation of feeding (e.g. Chiba 1961, Pedersen 1984, Talbot et al. 1984, Shepherd \& Mills 1996; see Table 1). In one study, prey passed through the guts of bay anchovy Anchoa mitchilli within minutes during continuous feeding (Chitty 1981). Correspondingly, GER calculated using Eq. (5) was employed when a larva was not feeding (e.g. at the onset of darkness), and the rate was tripled during periods when feeding was continuous.

During any time step, the ingested mass of prey was limited by the available empty space in the gut, which was based upon previous gut fullness and the rate of removal of food from the gut per time step. The maximum capacity of the gut was based upon the lengthspecific maximum dry mass of prey found within the guts of larvae of 10 different marine fish species (Pepin \& Penney 2000, their Fig. 2). The pooled (digitized) data indicated that the mean $( \pm \mathrm{SE})$ maximum gut prey biomass increased isometrically with larval size and was equal to $6.4(0.7) \%$ of larval dry mass (Fig. 1B). In this case, if foraging model estimates for $C$ were greater than the maximum capacity of the gut, the product of Eq. (3) $(A E)$ and the maximum capacity of the gut were used to limit assimilated $C$.

Case 3-digestive capacity: Case 3 was based upon the relationships among $C, G E R$ and $A E$, as affected by both larval body size and temperature. Results of laboratory studies on a variety of organisms (i.e. mollusks, insects, rotifers, copepods) including fish larvae indicated that $A E$ tends to decline when foraging takes place within increasing prey concentrations (PC) (Doohan 1973, Dagg \& Walker 1978, Boehlert \& Yoklavich 1984, Broekhuizen et al. 2002). This is thought to be associated with the positive relationship between GER and PC. In copepods, the shapes of the $G E R-P C$ relationship and the $G E R-A E$ relationship 
Table 1. Gut evacuation rates for marine and freshwater fish larvae and early juveniles of different species at different body sizes, temperatures $(T)$ and prey concentrations. In all cases, prey were zooplankton (either calanoids, cyclopoids, or daphnids), except for rockfish (ground squid) and Atlantic salmon (pellet diet). dph: days post-hatch; n.p.: not provided

\begin{tabular}{|c|c|c|c|c|c|c|c|c|}
\hline Species & $\begin{array}{l}\text { Age } \\
\text { (dph) }\end{array}$ & \multicolumn{2}{|c|}{$\begin{array}{c}\text { Length } \\
\text { (mean, range) } \\
\text { min. max. }\end{array}$} & $\begin{array}{c}\mathrm{T} \\
\left({ }^{\circ} \mathrm{C}\right)\end{array}$ & $\begin{array}{c}\text { Prey } \\
\text { concentration } \\
\left(\text { no. } ~^{-1}\right)\end{array}$ & $\begin{array}{r}\text { Evacu } \\
\text { Single meal } \\
\left(\mathrm{h}^{-1}\right)\end{array}$ & $\begin{array}{l}\text { Constant feeding } \\
\qquad\left(\mathrm{h}^{-1}\right)\end{array}$ & Source \\
\hline \multicolumn{9}{|l|}{ Marine species } \\
\hline Clupea harengus & n.p. & 10 & 12 & $\begin{array}{c}7 \\
11 \\
15\end{array}$ & n.p. & $\begin{array}{l}0.111 \\
0.200 \\
0.222\end{array}$ & & Blaxter (1962) \\
\hline Clupea harengus & 12 & 9 & 9 & $\begin{array}{c}8 \\
15\end{array}$ & n.p. & $\begin{array}{l}0.125 \\
0.250\end{array}$ & & Blaxter (1965) \\
\hline Clupea harengus & $8-22$ & 10.5 & 12 & $6-9$ & $4-5 \times 10^{3}$ & 0.667 & & Fossum (1983) \\
\hline Clupea harengus & $26-40$ & 12.5 & 18.1 & 9.5 & $0.011-0.198$ & 0.400 & 0.706 & Pedersen (1984) \\
\hline Clupea harengus & $21-63$ & n.p. & n.p. & 9.2 & $\begin{array}{c}3 \times 10^{1}-10^{2} \\
3 \times 10^{3} \\
3 \times 10^{4}\end{array}$ & $\begin{array}{c}0.143 \\
0.200-0.333 \\
0.170-0.250\end{array}$ & & Werner \& Blaxter (1979) \\
\hline Clupea harengus & & 35 & 74 & n.p. & in situ & 0.178 & & Arrhenius \& Hansson (1994) \\
\hline Cynoscion regalis & n.p. & 60 & 70 & 24 & n.p. & $0.121-0.219$ & & Lankford \& Targett (1997) \\
\hline Gadus morhua & 7 & & $(4-5)$ & 5 & n.p. & $0.500-0.667$ & & Tilseth \& Ellertsen (1984) \\
\hline Logadon rhomboids & & & & & in situ & 0.380 & & Peters \& Kjelson (1975) \\
\hline Sardinops sagax & & 10.1 & 13.9 & 20 & in situ & $0.250-0.500$ & & Herrera \& Balbontin (1983) \\
\hline Sebastes malanops & n.p. & 35 & 93 & $\begin{array}{c}7 \\
12 \\
18\end{array}$ & $\begin{array}{l}\text { ad libitum } \\
\text { ad libitum } \\
\text { ad libitum }\end{array}$ & $\begin{array}{l}0.019 \\
0.029 \\
0.038\end{array}$ & & Boehlert \& Yoklavich (1983) \\
\hline Sprattus sprattus & n.p. & 13 & 16 & $8-15$ & in situ & 0.460 & & M. A. Peck et al. (unpubl. data) \\
\hline Syngnathus fuscus & n.p. & 150 & 200 & $\begin{array}{l}15 \\
23 \\
27\end{array}$ & $\begin{array}{l}\text { n.p. } \\
\text { n.p. } \\
\text { n.p. }\end{array}$ & $\begin{array}{l}0.038 \\
0.078 \\
0.107\end{array}$ & & Ryer \& Boehlert (1983) \\
\hline Theragra chalcogramma & $<7$ & & $(5.92)$ & 6.2 & $1200-1500$ & $0.207-0.246$ & & Canino \& Bailey (1995) \\
\hline Thunnus alalunga & n.p. & 2.7 & 10 & 26 & in situ & $0.333-0.250$ & & Young \& Davis (1990) \\
\hline Thunnus maccoyii & n.p. & 2.7 & 10 & 26 & in situ & $0.250-0.333$ & & Young \& Davis (1990) \\
\hline Trachurus declivis. & n.p. & 2.4 & 14.3 & $15-18$ & in situ & $0.167-0.250$ & & Young \& Davis (1992) \\
\hline Ulvaria subbifurvata & n.p. & 4 & 13 & 14 & in situ & $0.165-0.290$ & & Bochdansky et al. (2006) \\
\hline Freshwater species & & & & & & & & \\
\hline Cyprinus carpio & n.p. & 8 & 12 & $18-29$ & & 0.050 & $0.125-1.000$ & Chiba (1961) \\
\hline Coregonus albula & 14 & & 8.7 & 18 & n.p. & 0.280 & & Karjalainen et al. (1991) \\
\hline Dorosoma cepedianum & n.p. & 25 & 89 & 21 & n.p. & $0.130-0.250$ & $0.550-1.250$ & Shepherd \& Mills (1996) \\
\hline Micropterus salmoides & n.p. & 20 & $60^{\mathrm{a}}$ & $\begin{array}{l}18 \\
23\end{array}$ & n.p. & $\begin{array}{l}0.192 \\
0.263\end{array}$ & $\begin{array}{l}0.357 \\
0.500\end{array}$ & Laurence (1971) \\
\hline Perca flavescens & n.p. & & $\begin{array}{c}(17-19.5) \\
30-40 \\
(60)\end{array}$ & $\begin{array}{l}21 \\
22 \\
15\end{array}$ & $\begin{array}{l}\text { n.p. } \\
\text { n.p. } \\
\text { n.p. }\end{array}$ & $\begin{array}{l}\text { n.p. } \\
0.154 \\
0.083\end{array}$ & $\begin{array}{l}1.667 \\
0.667 \\
0.167\end{array}$ & Noble (1973) \\
\hline Perca flavescens & n.p. & 20 & 69 & $14-21$ & n.p. & n.p. & $0.417-3.333$ & Mills et al. (1984) \\
\hline Perca fluviatilis & n.p. & & $(13.1)$ & n.p. & field & 0.400 & & Worischka \& Mehner (1998) \\
\hline Salmo salar & n.p. & 43 & 99 & $9-13$ & n.p. & 0.017 & 0.068 & Talbot et al. (1984) \\
\hline Stizostedion lucioperca & n.p. & & 10.6 & n.p. & field & 0.430 & & Worischka \& Mehner (1998) \\
\hline Stizostedion vitreum & n.p. & 10.4 & 16.2 & $\begin{array}{l}15 \\
20 \\
25\end{array}$ & $\begin{array}{l}\text { n.p. } \\
\text { n.p. } \\
\text { n.p. }\end{array}$ & $\begin{array}{l}0.109 \\
0.245 \\
0.106\end{array}$ & & Johnston \& Mathias (1996) \\
\hline Stizostedion vitreum & 21 & & $(29.4)$ & 22 & n.p. & 0.167 & 0.500 & Corazza \& Nickum (1983) \\
\hline
\end{tabular}

were described using both power and exponential models (e.g. Dagg \& Walker 1978, Xu \& Wang 2001, Besiktepe \& Dam 2002). In fish, a negative correlation between $G E R$ and $A E$ was reported by Johnston \& Mathias (1996) for zooplanktivorous walleye Stizostedion vitreum larvae and by Elliott (1976) working on juvenile brown trout Salmo trutta, but the functional form of the relationship was not quantified.

Working with Pacific herring Clupea pallasi larvae, Boehlert \& Yoklavich (1984) observed that carbon retained in the guts of fish feeding on rotifers Brachionus sp. and brine shrimp Artemia sp. nauplii decreased with increasing $\mathrm{PC}$, indicating reduced $A E$. This suggested that the digestive capacity decreased with increasing feeding rates. Although GER increases with temperature, so does the activity of digestive enzymes (e.g. Alarcón et al. 1995, Gelman et al. 2003), suggesting that digestive capacity increases with increasing temperature, although few laboratory data exist on this topic for marine fish larvae. 

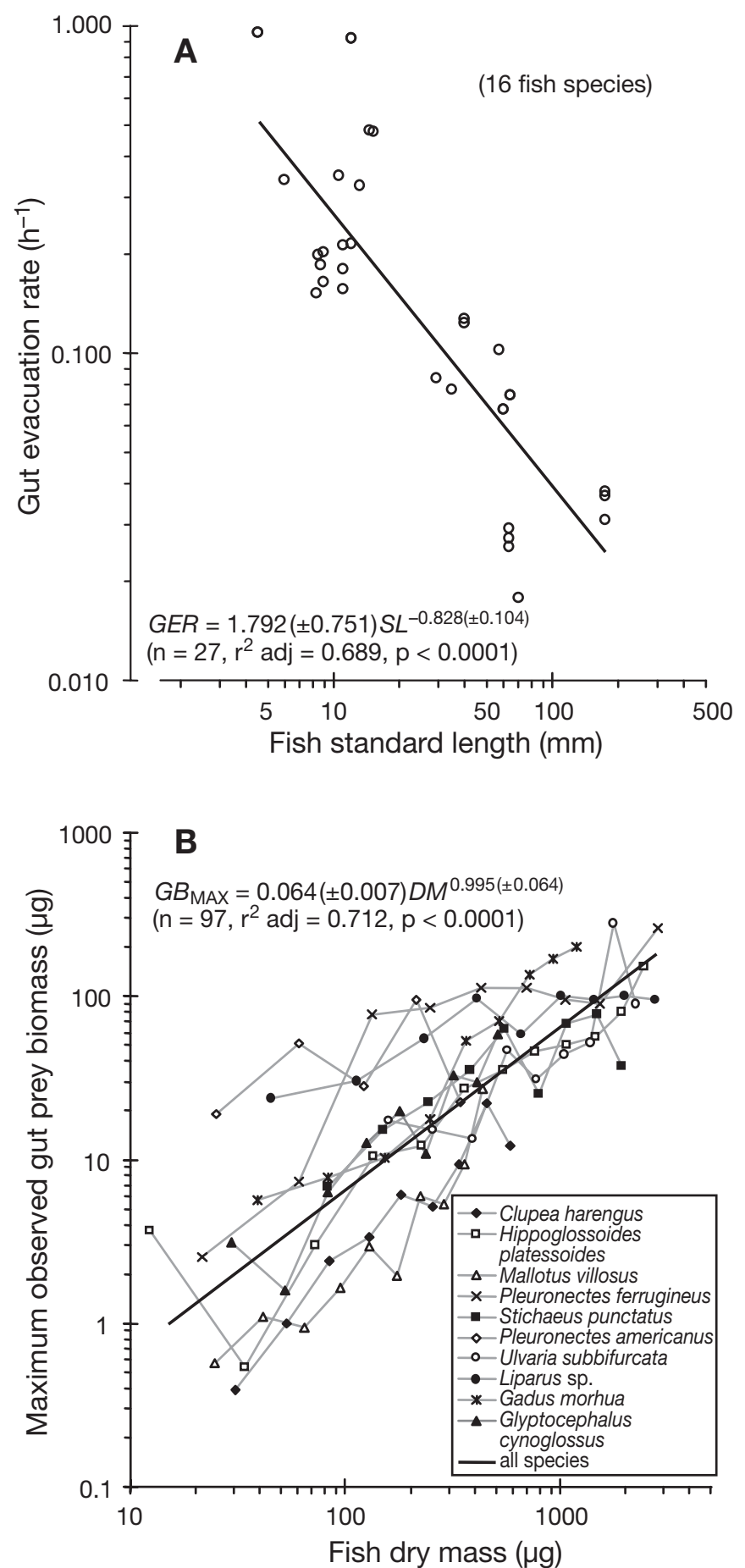

Fig. 1. Literature data on gut capacity and gut evacuation rate $(G E R)$ for marine and freshwater teleost larvae. (A) Temperature-adjusted GER $\left(\mathrm{h}^{-1}\right)$ versus body length (standard length, $S L, \mathrm{~mm}$ ) for 16 teleost species. Data are those reported in Table 1. All rates were expressed relative to $12^{\circ} \mathrm{C}$ using a $Q_{10}$ of 2.0. (B) Maximum prey biomass ( $\left.G B_{\mathrm{MAX}}, \mu \mathrm{g}\right)$ measured in the guts of larvae of each of 10 marine fish species versus larval dry mass $(D M, \mu \mathrm{g})$. Data were digitized from Pepin \& Penney (2000, their Fig. 2). The regression line is the best fit for the pooled data. In both panels, mean $( \pm \mathrm{SE})$ regression parameter estimates are shown
In summary, the literature on fish physiology support the method explored in Case 3, in which $A E$ and GER both change with body size and are negatively correlated with one another. In this case, a temperaturedependent GER and knowledge of the maximum biomass of prey in guts was used to define a body size-specific maximum gut capacity $\left(G u t_{\mathrm{CAP}}\right.$ ) (similar to the 'plug-flow reactor' model, e.g. see Canino \& Bailey 1995). After Gut CAP $_{\text {was }}$ exceeded, an exponential decrease in $A E$ with increasing food consumption rate was assumed (Fig. 2), based upon the work of Boehlert \& Yoklavich (1984):

$$
A E= \begin{cases}A E_{\text {std }} & \forall C \leq G u t_{\mathrm{CAP}} \\ A E_{\text {std }} \mathrm{e}^{-9.441\left(\frac{C-G u t_{\mathrm{CAP}}}{M_{\mathrm{D}}}\right)} & \forall C>G u t_{\mathrm{CAP}}\end{cases}
$$

Due to a lack of information, the decrease in $A E$ after

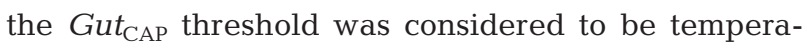
ture independent in one case (Case 3A) and temperature dependent in another (Case 3B) (see Fig. 2 insert). Furthermore, to be ecologically and/or biologically reasonable, $C$ increased with increasing prey concentration until the point where the product of $C$ and $A E$ declined (i.e. where the gross energy obtained by the larvae was maximal). In this study, no attempt was made to assess the potential impact of prey composition, another factor that affects both $G E R$ and $A E$ in fishes (Karjalainen et al. 1991, Lankford \& Targett 1997).

Model simulations and prey fields. Three different $8 \mathrm{~d}$ simulations (1-dimensional model, $1 \mathrm{~h}$ time step) were run using $12 \mathrm{~mm} S L$ ( 275 $\mu \mathrm{g}$ dry mass) sprat larvae that foraged during a $14 \mathrm{~h}$ photoperiod. In each simulation, we used $C_{\text {MAX }}$ (Case 1), GER (Case 2), or $A E$ (Case 3) feeding limits. In Simulation 1, growth rates $\left(\mathrm{mm} \mathrm{d}^{-1}\right)$ were quantified for larvae foraging at each of 8 prey concentrations and 3 temperatures (Table 2). In Simulation 2, the effect of different magnitudes of prey patchiness on modeled growth rates was investigated by allowing larvae to forage for different amounts of time within prey patches of 2-, 5-, or 10-fold increased prey concentrations. In Simulation 3, larvae experienced random fluctuations in the prey field and food consumption; assimilated food and growth rates within each hourly time step were compared among the 3 cases (1, 2 and 3$)$.

Copepods form the vast majority of prey consumed by the larvae of marine fishes, including sprat (Dickmann 2006). The range of copepod concentrations and the relative abundance of different size classes used in this study were based upon zooplankton measurements at German GLOBEC Station 32 in the southern North Sea $\left(54.66^{\circ} \mathrm{N}, 7.66^{\circ} \mathrm{E}\right)$. At Station 32, the total abundance of the 200 to $600 \mu \mathrm{m}$ size classes of the 3 dominant copepods in larval sprat guts (Acartia spp., 


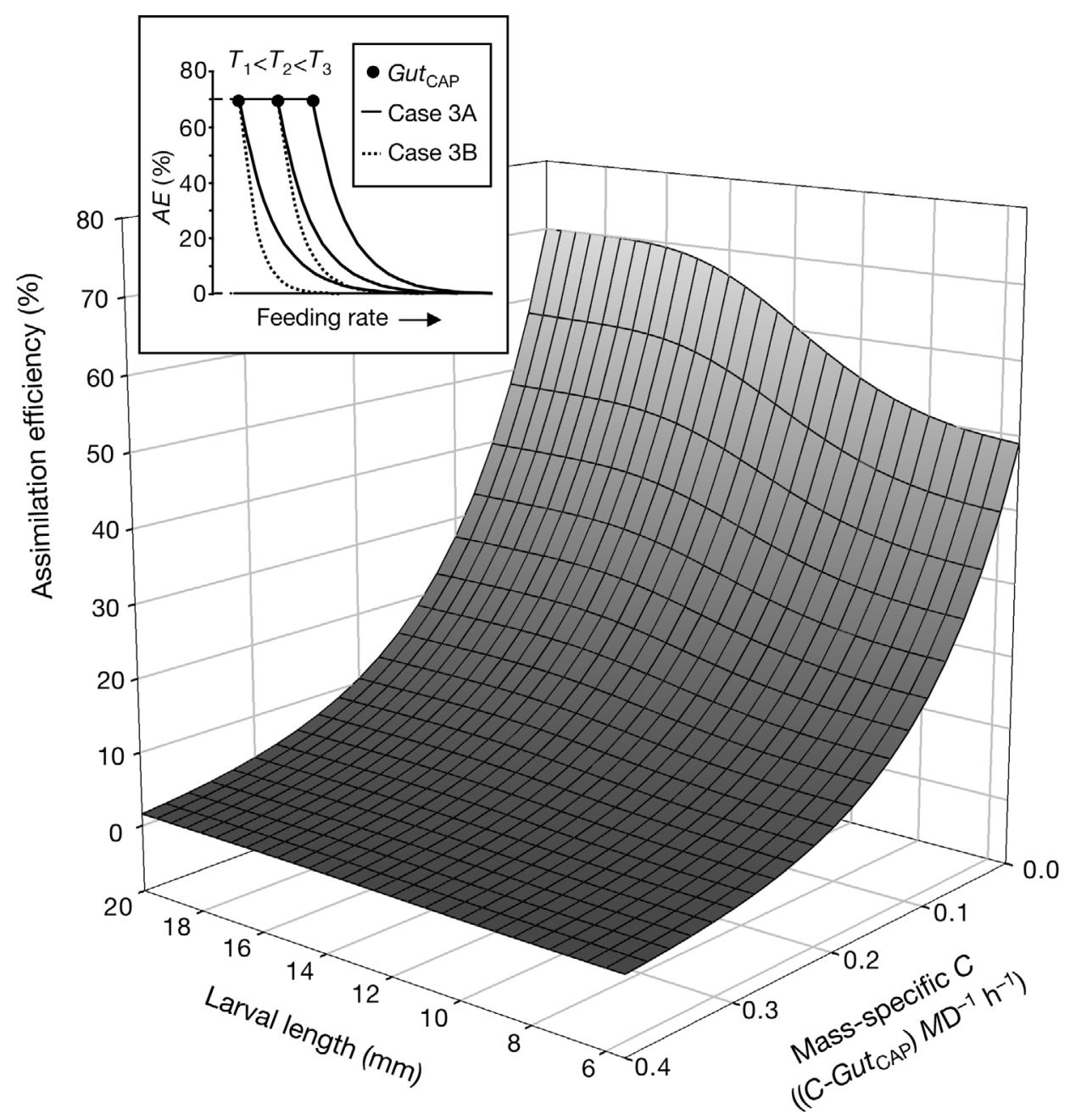

Fig. 2. Case 3 assimilation efficiency $(A E, \%)$ versus fish size (mm length) and food consumption rate in relative units of gut capacity $\left(G u t_{\mathrm{CAP}}\right)$. A relative consumption rate value of 0.0 indicates that the rate of food consumption within a model time step was equal to Gut $t_{\mathrm{CAP}}$. Insert: Diagram depicting the decrease in $A E$ at each of 3 different temperatures $(T)$. In Case $3 \mathrm{~A}$, the same decrease was used at each temperature. In Case 3B, the decrease was more rapid with decreasing temperature, a response that was based upon considerations of larval growth rates and threshold prey concentrations at different temperatures

Table 2. Summary information for $8 \mathrm{~d}$ individual-based model simulations comparing $C_{\mathrm{MAX}}, G E R$ - and $A E$-based limits to larval fish food consumption rate. Copepod concentration is given as the relative abundance in $50 \mu \mathrm{m}$ size classes 200:250: ... $550 \mu \mathrm{m}=1.00: 0.80: 0.64: 0.51: 0.41: 0.32: 0.26: 0.21$. n.a.: not applicable

\begin{tabular}{|c|c|c|c|c|c|}
\hline \multirow[t]{2}{*}{ Simulation } & \multirow{2}{*}{$\begin{array}{c}\text { Temp. } \\
\left({ }^{\circ} \mathrm{C}\right)\end{array}$} & \multirow[t]{2}{*}{ Prey patches } & \multicolumn{3}{|c|}{ Copepod concentration (no. $\mathrm{l}^{-1}$ ) } \\
\hline & & & Mean & $\begin{array}{l}\text { Outside } \\
\text { patch }\end{array}$ & $\begin{array}{l}\text { Inside } \\
\text { patch }\end{array}$ \\
\hline 1 & $5,12,18$ & No & $\begin{array}{c}1.5,1.7,2.0,2.6 \\
3.4,5.1,10.2,51.0\end{array}$ & n.a. & n.a. \\
\hline $2 \mathrm{a}$ & 12 & Yes $(2 \times)$ & 21.0 & 14.8 & 29.7 \\
\hline $2 b$ & 12 & Yes $(5 \times)$ & 21.0 & 9.4 & 47.0 \\
\hline $2 \mathrm{c}$ & 12 & Yes $(10 \times)$ & 21.0 & 6.6 & 66.4 \\
\hline 3 & 12 & Yes (random) & 4.9 & (0.3 to & $30.0)^{\mathrm{a}}$ \\
\hline
\end{tabular}

Temora longicornis and Pseudocalanus elongatus) was $\sim 21.0 \mathrm{l}^{-1}$. Starting at 200 $\mu \mathrm{m}$, copepod abundance $\left(A B\right.$, no. $\left.1^{-1}\right)$ decreased exponentially with increasing $50 \mu \mathrm{m}$ size class ( $S C$ ) as: $A B=12.5 \times$ $\mathrm{e}^{-0.0045 \times S C}\left(\mathrm{r}^{2}=0.96, \mathrm{p}<0.001\right)$. The range in prey sizes eaten by sprat increases with increasing larval length; $12 \mathrm{~mm} S L$ larvae eat prey of 200 to $\sim 500$ $\mu \mathrm{m}$, while $18 \mathrm{~mm} S L$ sprat can eat 800 $\mu \mathrm{m}$ prey (Dickmann 2006). Although information on copepod patchiness in the southern North Sea is lacking, Owen (1989) reported that small-scale ( $\mathrm{dm}$ to $\mathrm{m}$ ) plankton patches in the Pacific most commonly contained 2-fold 
higher concentrations of organisms, but that patch concentrations exceeded mean concentrations by $>10$ fold in some cases. We used (at most) a 10-fold range in prey concentrations within and outside patches in Simulation 2 and a 10-fold increase above the mean concentration in Simulation 3 (Table 2).

\section{RESULTS}

\section{Temperature, prey and growth}

Simulation 1 results indicated that (1) growth rate $(G)$ was positively correlated to temperature $(T)$ at higher prey concentrations, (2) G was negatively correlated to $T$ at low prey concentrations and (3) the threshold prey concentration at which $G$ was food-
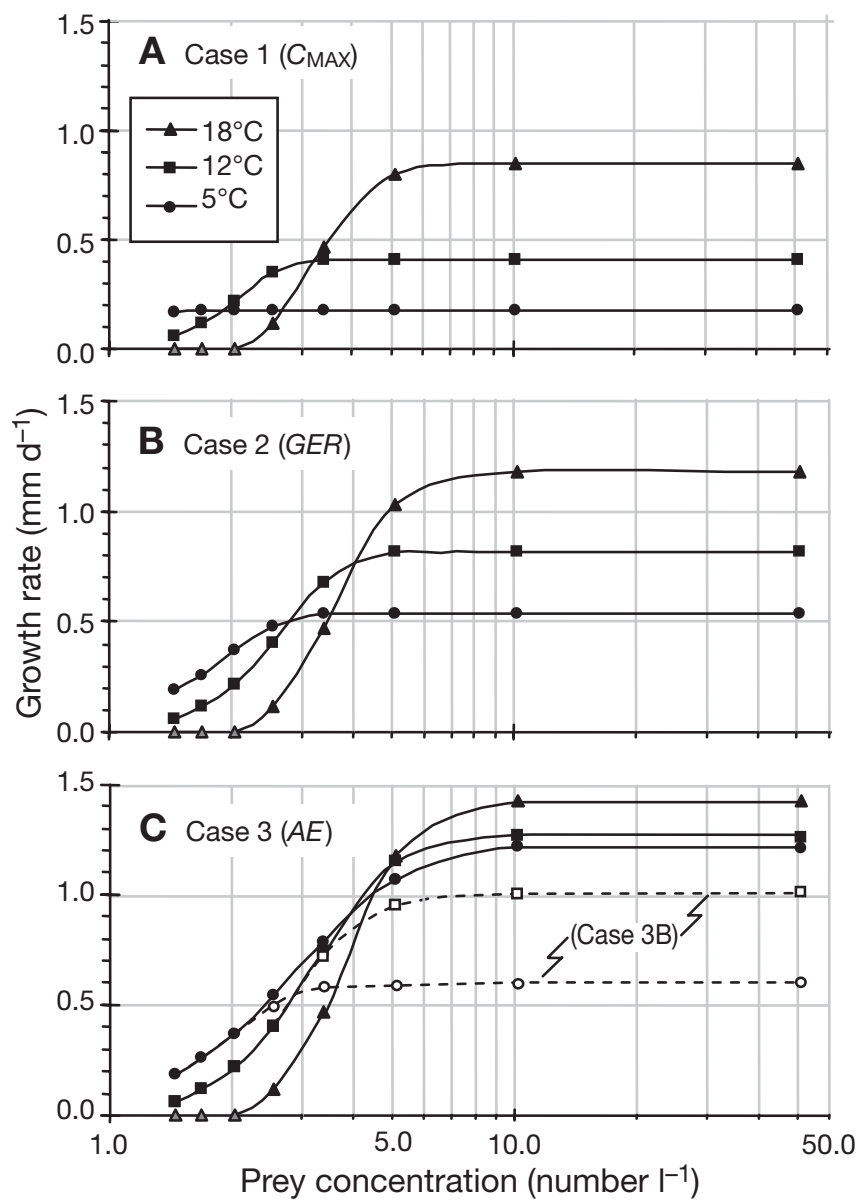

Fig. 3. Simulated growth rates $\left(\mathrm{mm} \mathrm{d}^{-1}\right)$ of larvae after foraging for $8 \mathrm{~d}$ at 8 different prey concentrations at each of 3 temperatures $\left(5,12\right.$, or $\left.18^{\circ} \mathrm{C}\right)$. Each panel depicts a different method of limiting modeled food consumption. Unfilled symbols in Panel $\mathrm{C}$ denote growth rates for larvae limited using the Case 3B approach (see Fig. 2). Gray-filled triangles denote mortality. All larvae were $12 \mathrm{~mm} \mathrm{SL}$ at the start of simulations limited increased with increasing $T$ (Fig. 3). The relationship between $G$ and prey concentration had the same functional form in all 3 cases, but threshold prey concentrations were slightly higher in the GER and $A E$ cases. The effect of $T$ on $G$ and on prey threshold concentration was similar in the first 2 cases, but was relatively small in Case 3A $(A E)$. However, the influence of $T$ on $G$ was similar in all 3 cases when the decrease in $A E$ with increasing $C$ (above gut capacity) was temperature dependent (this is Case 3B, see Figs. $2 \& 3$ ). Relative to $C_{\mathrm{MAX}}$, maximal growth rates resulting from $G E R$ and $A E$ limits were higher at the same temperatures and prey concentrations, but were in closer agreement with $G$ at $C_{\text {MAx }}$ when Case 3B was employed.

\section{Prey patches}

When GER or $A E$ feeding limits were used in Simulation 2, relative larval growth rates were increased by $\geq 10 \%$ when larvae spent only $12 \%$ of the $8 \mathrm{~d}$ foraging period within patches having 10 -fold higher prey concentrations than outside patches (Fig. 4). Using the $G E R$ - and $A E$-based limits, when prey patches had

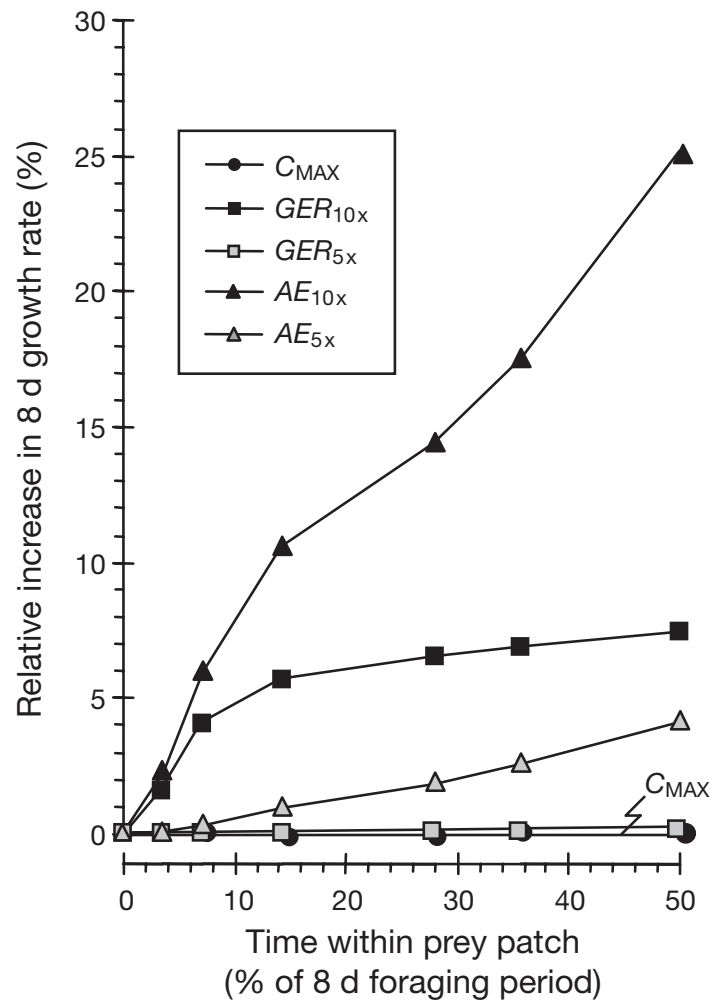

Fig. 4. Percentage increase in $8 \mathrm{~d}$ growth rate versus the duration of time within a patch ( $\%$ foraging time). All values are case specific and relative to the no-patch condition (0). Growth responses to 5- and 10-fold patch prey concentrations are shown (see Table 2, Simulation 2a to c) 
5-fold higher prey concentrations, the relative changes in growth were smaller. At 2-fold differences in prey concentration, no growth differences were detected because prey concentrations were above growth thresholds both outside and inside prey patches. Due to the lower prey threshold for maximum growth, relative growth of larvae was unchanged by the presence of prey patches when the $C_{\mathrm{MAX}}$ limit was employed.

\section{Fluctuating prey fields}

The differences among the 3 approaches to limit $C$ were clearly evident when larvae were exposed to random fluctuations in the prey field in Simulation 3. For example, no differences in assimilated $C$ were noted within and outside of prey patches using $C_{\mathrm{MAX}}$, whereas 2- to 3-fold higher assimilated $C$ was noted within patches using GER and $A E$ approaches (Fig. 5). Within this random encounter simulation, larval $C$ was saturated at concentrations of $\geq 15$ copepodites $\mathbf{l}^{-1}$, which were randomly encountered 11 times over the $8 \mathrm{~d}$ period. At these high concentrations, mean $( \pm \mathrm{SD}) C$ was equivalent to 41.3 (1.0), 56.3 (3.1) and $173.8(1.1) \%$ larval dry mass $\mathrm{d}^{-1}$ (hourly rates $\times 14 \mathrm{~h}$ foraging period) when feeding was limited by $C_{\mathrm{MAX}}, G E R$ and $A E$, respectively. The mean $( \pm \mathrm{SE})$ assimilated ration during the same periods was equivalent to 25.4 (0.2), 36.4 (1.0) and 49.7 (8.8)\% larval dry mass $\mathrm{d}^{-1}$ in the same 3 cases. Estimates of assimilated $C$ were more similar among the 3 cases, since $A E$ within Case 3 decreased from a median value of $64 \%$ at concentrations $<4$ copepods $l^{-1}$ to $\sim 28 \%$ when larvae fed intensively within patches containing 15 to 40 copepods $\mathrm{l}^{-1}$.

Foraging estimates of $C$ (Eq. 2) and the limits to $C$ imposed by each of the 3 approaches $\left(C_{\mathrm{MAX}}, G E R\right.$ and $A E$ ) were generally in close agreement at relatively low prey concentrations (Fig. 6A). However, at relatively high prey concentrations, foraging model estimates of $C$ based on Eq. (2) were 2- to 4 -fold higher than the highest $C$ limit, the limit imposed by $A E$ in Case 3 (Fig. 6B).

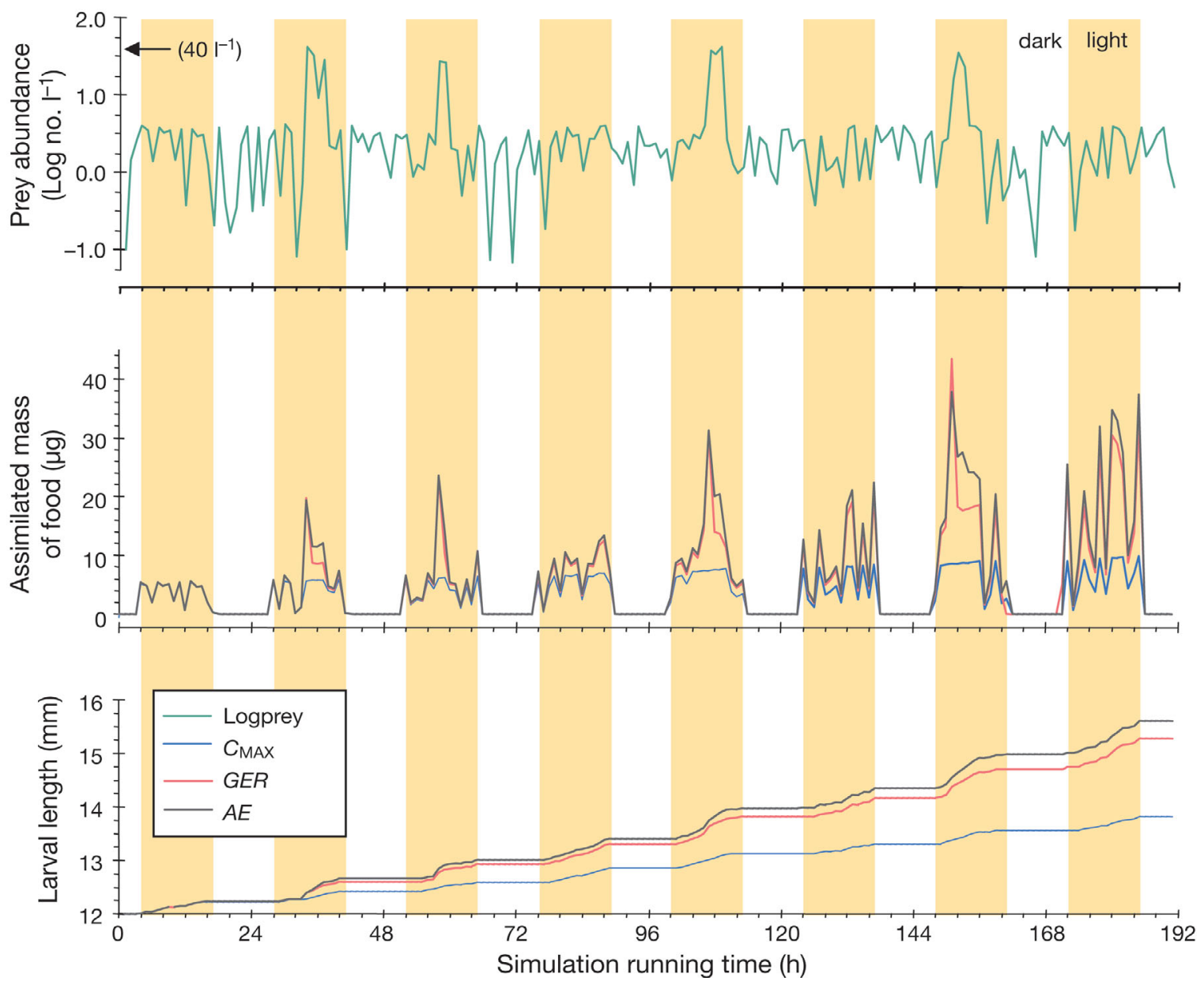

Fig. 5. Individual-based method simulation of random fluctuations in prey concentration and corresponding effect on changes in assimilated food and larval size $(\mathrm{mm})$ per $1 \mathrm{~h}$ time step over the course of $8 \mathrm{~d}$. The light regime and the value for peak prey abundance within a patch (upper panel) are indicated 


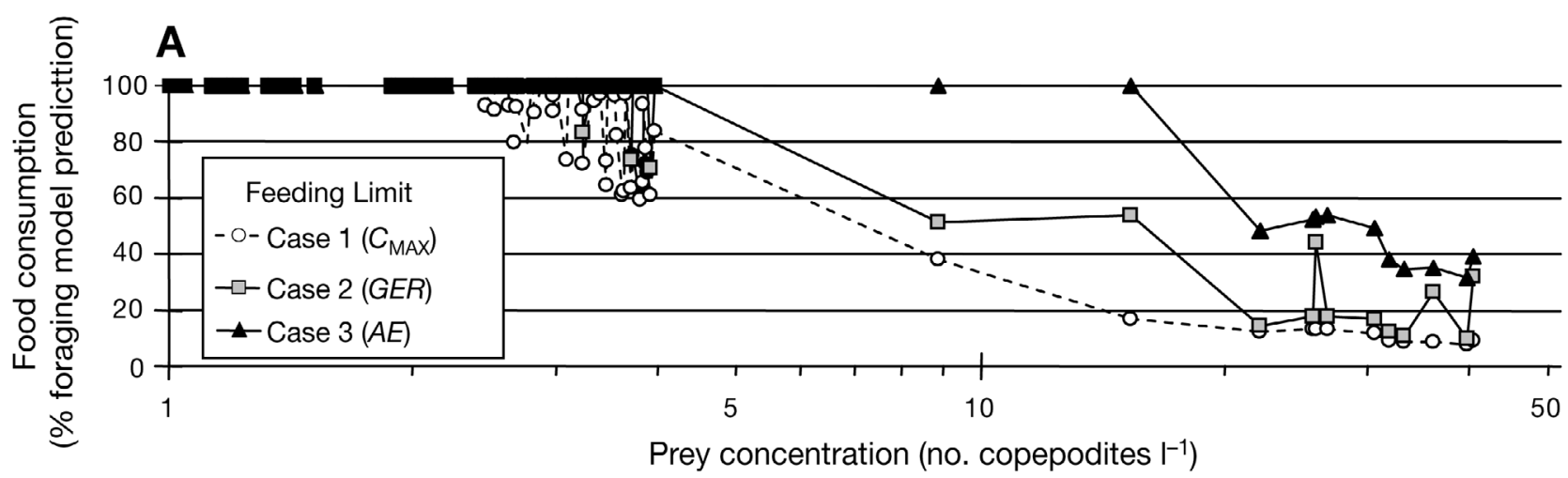

B

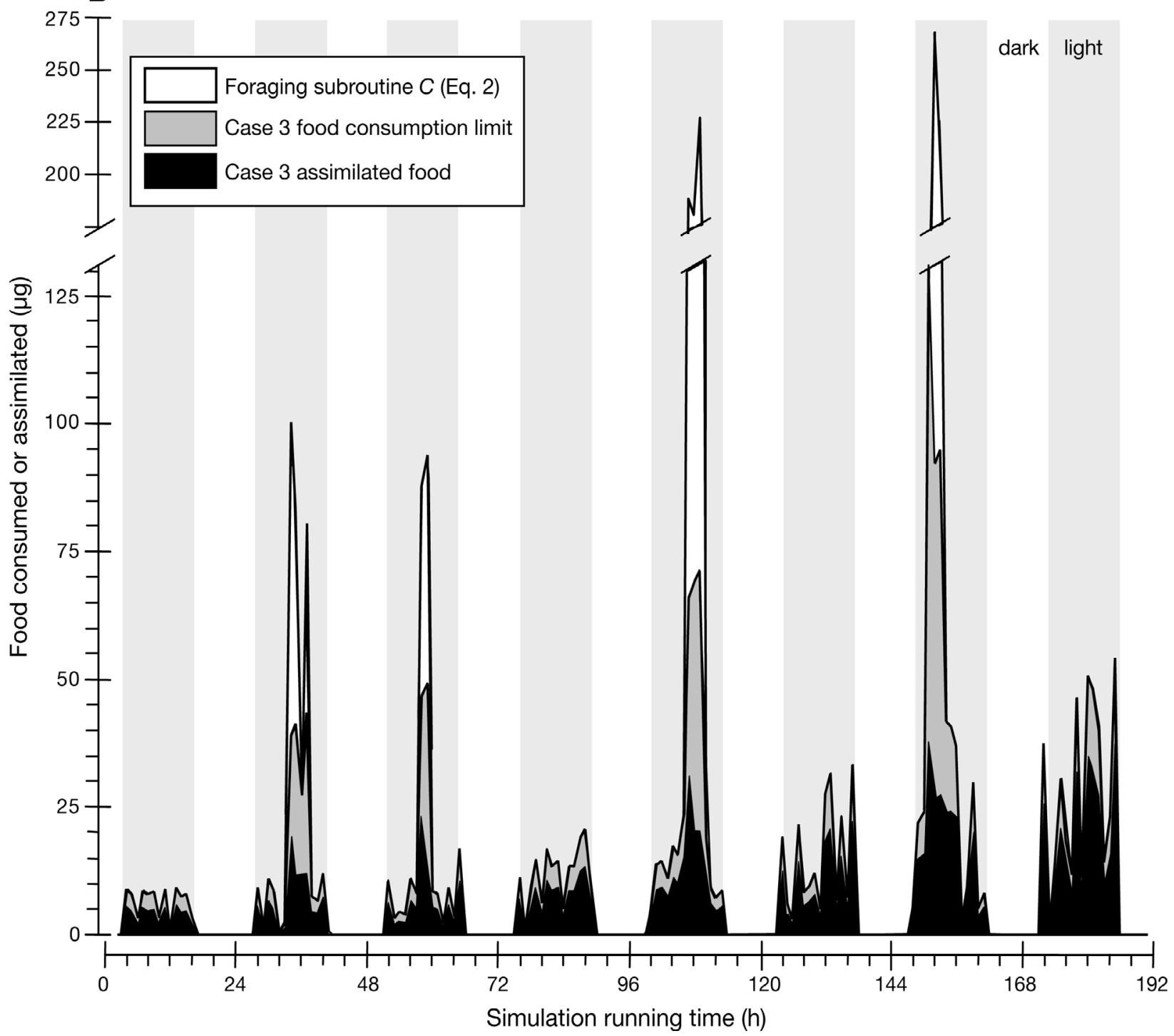

Fig. 6. (A) Food consumption rate $(C)$ as limited by Case $1\left(C_{\mathrm{MAX}}\right)$, Case $2(G E R)$ and Case 3A $(A E)$ relative to the individualbased method foraging subroutine estimate of $C$ (based on Eq. 2 in the text) at different prey concentrations. Prey concentrations were those that were randomly encountered within model Simulation 3. (B) Comparison of foraging subroutine $C$, Case 3Alimited $C$ and Case 3A-limited assimilated food $(C \times A E)$ in each $1 \mathrm{~h}$ time step during the course of model Simulation 3. The randomly fluctuating prey field is shown in Fig. 5 


\section{DISCUSSION}

\section{Temperature, prey and growth}

The results of our simulations performed at different, homogenous prey concentrations were consistent with expectations concerning larval fish physiology and interactions among temperature $(T)$, feeding rate $(C)$ and growth rate $(G)$. Interestingly, for the effect of temperature on growth in Case $3(A E)$ to be similar to that in the other 2 cases, the decrease in $A E$ with increasing $C$ (above gut capacity) had to be temperature dependent (this is Case 3B, see Figs. 2 \& 3). We are unaware of any studies comparing the decline in $A E$ with increasing $C$ at different temperatures. However, the formulation appears to be biologically reasonable and laboratory studies should be conducted to test the validity of this model result. In the following discussion, we avoid further discussion of temperature and focus on comparing the 3 cases at the same temperature.

Clearly, growth rates of larval fish should be food limited in environments with low prey concentrations. However, the threshold prey concentrations reported in different studies to limit larval marine fish foraging and growth rates are equivocal. Based upon a review of laboratory functional response experiments conducted on 8 species of marine fish larvae, MacKenzie et al. (1990) calculated a threshold prey concentration of $179 \mu \mathrm{g} \mathrm{l}^{-1}$ below which larval fish $C$ was food limited. Given the conversions used in their study, this corresponds to a concentration of $\sim 660$ nauplii $\mathrm{l}^{-1}$ or $\sim 80$ copepodites $\mathrm{l}^{-1}$. In the present study, simulated growth rates declined ( $C$ was not maximal) at concentrations of 3 to 5 copepodites $\mathrm{l}^{-1}$ and were highest (feeding was maximal) at $\sim 10$ copepodites $\mathrm{l}^{-1}$ (Fig. 3). Our simulation predictions agreed well with the results of laboratory studies evaluating the effects of prey concentration on food searching and capture success of prey by larval marine fish (Munk \& Kiørboe 1985, Munk 1995). In one study, 5.7 to $6.9 \mathrm{~mm} S L$ larval Atlantic cod foraged effectively at prey concentrations

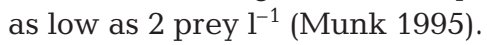

Our estimates of $C$ based upon the $C_{\mathrm{MAX}}$ limit $(41.3 \%)$ and GER limit (56.3\%) were similar to those obtained in a meta-analysis of 9 laboratory studies quantifying feeding rates by marine fish larvae (MacKenzie et al. 1990). In that study, ingestion by a $132.4 \mu \mathrm{g}$ dry mass larva was equal to $75.8 \mu \mathrm{g} \mathrm{d}^{-1}(57 \%$ $M_{\mathrm{D}}$ ) at $18.7^{\circ} \mathrm{C}$, and estimates of relative ingestion varied by a factor of about 2 for the 12 species examined. Such interspecific differences underscore the problems that can arise whenever a 'generic' approach is taken to parameterize a model for a specific species. We illustrated this via the discrepancies between growth estimates using a $C_{\text {MAX }}$ parameter (based upon data collected on sprat) and the other 2 limits (interspecific parameterization). However, without parameter 'tuning', 2-fold differences in growth estimates were apparent among the 3 approaches, which were well within the range of inter-specific differences reported for most vital rates in teleost larvae (e.g. Houde 1989, Govoni et al. 1986, MacKenzie et al. 1990, Houde \& Zastrow 1993).

When considered in light of values determined for the gross growth efficiency ( $G G E=100 \times G / C)$ of larval fish, our value for GGE (64\%) in Simulation 3 Case 3 ( $A E$ limit) was similar to that found in some species (Blennius pavo $=60 \%$, Clupea harengus $=62 \%)$, but higher than the average calculated for larvae of a number of species (MacKenzie et al. 1990, Houde \& Zastrow 1993). That our GGE value resulting from the $A E$ limit agreed with published accounts was somewhat unexpected, since (1) our IBM was parameterized based on data for clupeids (sprat and Atlantic herring), (2) GER, gut capacity ( $G u t_{\mathrm{CAP}}$ ) and feeding-induced limits to $A E$ were based upon data collected on a variety of nonclupeid species, and (3) no model tuning was used to adjust parameter values. A justifiable example of the latter would be adjustments made to active metabolism $\left(R_{\mathrm{A}}\right)$. Clearly, intensive feeding within patches would be expected to increase $R_{\mathrm{A}}$, leading to lower energy available for growth (and lower values of $G G E$ ).

\section{Prey patches and foraging}

Our simulation results suggested that static limits to $C$ such as $C_{\text {MAX }}$ may not be adequate when modeled larvae forage in habitats with marked spatial and/or temporal variability in prey resources. In Case 3 ( $A E$ based limit), larvae could exploit prey patches by consuming more food (at lower $A E$ ) per model time step. However, it should be noted that exploitation of prey patches in this manner could only benefit larvae (lead to higher growth rates) if prey concentrations outside the patch were lower than the growth-threshold prey concentration $\left(\sim 10\right.$ copepodites $\mathrm{l}^{-1}$, see Fig. 3$)$. The present simulation depicted a southern North Sea habitat having a mean copepodite concentration of $21.0 \mathrm{l}^{-1}$, with $2-, 5-$, or 10 -fold differences in concentrations within and outside patches (see Table 2). Foraging in this habitat, larvae benefited little (benefited much) from adopting a patch feeding strategy when prey concentrations in patches were $\leq 2$-fold ( $\geq 5$-fold) those outside patches.

An important finding of the present study was that, at high prey concentrations, a large discrepancy existed between foraging model estimates of $C$ and the limits to $C$ imposed by $C_{\mathrm{MAX}}, G E R$, or $A E$ approaches. At concentrations $>40$ copepodites $\mathrm{l}^{-1}$, the foraging 
model predicted 2- to 4 -fold higher $C$ than the limit imposed by Case 3 (where $C$ was highest among the 3 limits; see Fig. 6A). Differences between foraging model $C$ and the limits imposed by $C_{\text {MAX }}$ were not unexpected. A $C_{\text {MAX }}$ parameter is derived from massbased parameter rates of a balanced bioenergetics budget (e.g. metabolic losses and growth), while the foraging subroutine contains functions utilizing larval length (e.g. visual distance, capture success, swimming velocity). Since sprat larvae have relatively low mass-at-length compared to larvae of other teleosts (Peck et al. 2005), the foraging model prediction of $C$ (based on length) exceeds the estimates of $C$ required to obtain in situ growth rates (based on mass). However, the discrepancy of the foraging model estimates of $C$ and the limit imposed by both of the other approaches (Cases 2 \& 3) (e.g. see Fig. 6B) suggests that the current (commonly used) formulation of larval fish foraging yields unrealistically high $C$ when larval fish encounter high prey concentrations.

\section{Working knowledge}

The physiologically based approaches to limit food consumption explored in this study relied upon knowledge of $G E R$ and $A E$ and how these parameters were affected by changes in larval fish size, temperature and prey concentration. How robust are the estimates of GER? There appear to be many studies evaluating $G E R$ in fish, and the rates reported were similar after temperature and fish body size differences were taken into account. GER was generally between 0.2 and 0.5 $\mathrm{h}^{-1}$ for young larvae of a variety of marine and freshwater fish species, including 0.165 to 0.290 for larval radiated shanny Ulvaria subbifurvata (Bochdansky et al. 2006), 0.207 to 0.246 for walleye pollock Theragra chalcogramma (Canino \& Bailey 1995), 0.38 for pinfish Logadon rhomboids (Peters \& Kjelson 1975), 0.40 for perch Perca fluviatilis and 0.43 for zander Stizostedion lucioperca (Worischka \& Mehner 1998). GER for postlarval stages tended to be lower, and was between 0.13 and 0.29 for young-of-the-year Atlantic herring (Arrhenius \& Hansson 1994) and from 0.032 to 0.052 for larger, juvenile Atlantic salmon Salmo salar (Talbot et al. 1984). A 2- to 5-fold increase in GER during continuous feeding is also well documented. It appears as though laboratory studies indicating no effect of prey density on GER of larval and young juvenile fishes (e.g. Bochdansky \& Dielbel 2001, Bochdansky et al. 2006) measured GER in fish that were no longer feeding.

How robust are estimates of $A E$ ? Compared to $G E R$, far fewer studies have been conducted on $A E$ using fish larvae. 'Inasmuch as it has bearing on models of larval growth and survival, the question of changing digestive and assimilative abilities with larval development... warrants the most immediate attention' (Govoni et al. 1986, p. 73). This statement is still true today. The values of $A E$ differ depending upon the species. For example, $A E$ was about $90 \%$ (based on carbon contents of copepod prey) in 13 to $34 \mathrm{dph}$ (days post-hatch) Atlantic herring larvae (Pedersen \& Hjelmeland 1988), but a range of lower values (i.e. from 30 to $90 \%$ ) have also been reported (for reviews see Govoni et al. 1986, Houde \& Zastrow 1993). In the present study, the effect of body size (developmental state) was incorporated into $A E$ by evaluating literature data on a variety of species. It is reasonable to assume an improvement of $A E$ with increasing body size (developmental stage), and this has been shown in several studies (Govoni et al. 1986). However, the largest species-specific differences in $A E$ will undoubtedly be manifested in the effect of body size via differences among species in developmental characteristics. For this reason, more work is needed on $A E$ in larval fish. Our simulation results (Case 3B) suggested that growth rates at different temperatures were only reasonable when the reduction of $A E$ with increasing feeding rate was temperature dependent, and this should be tested.

\section{CONCLUSIONS}

Feedbacks between a marine fish larva and its environment have recently been explored using an IBM approach (e.g. behavioral modifications necessary to optimally forage within prey patches; Pitchford et al. 2003). In the present study, we included an interaction between the feeding physiology of a larva (consumption, digestion and assimilation of food) and characteristics of its prey field (different concentrations having patchy or homogenous distributions). Two physiologically based alternatives to $C_{\mathrm{MAX}}$ were parameterized, based upon the available literature on $G E R$ and $A E$ for the larvae of a variety of freshwater and marine fish species. We recommend that larval fish IBMs utilizing foraging and growth subroutines also employ physiologically based limits to food consumption rate and that non-mechanistic parameters $\left(C_{\mathrm{MAX}}\right.$ and/or $\left.G_{\mathrm{MAX}}\right)$ be avoided. Employing mechanistic limits to feeding may be critical if models attempt to explore (and hope to understand) the consequences of both short- and long-term prey field variability on the growth and survival of marine fish larvae.

Acknowledgements. We are grateful to Susanne Tamm for the in situ prey abundance data and also thank Wilfried Kühn, Corinna Schrum and Mike St. John for thoughtful discussions relating to the IBM formulation. This research was presented 
at the 'Workshop on advancements in modeling physicalbiological interactions in fish early-life history: recommended practices and future directions' that took place in Nantes, France, from 3 to 5 April 2006. The present study was funded by the 'GLOBEC-Germany' program (FKZ No. 03F0320E), by the German 'AQUASHIFT' program (DFG No. JO556/1-1) and by 'UNCOVER' (EU, STREP No. 022717).

\section{LITERATURE CITED}

Alarcón FJ, Moyano FJ, Díaz M (1995) Digestión proteica en peces marinos: una visión general. In: Castello F, Calderer A (eds) Actas V Congreso Nacional de Acuicultura. Universitat de Barcelona, Barcelona, p 455-460

Almatar SM (1984) Effects of acute changes in temperature and salinity on the oxygen uptake of larvae of herring (Clupea harengus) and plaice (Pleuronectes platessa). Mar Biol 80:117-124

Arrhenius F, Hansson S (1994) In situ food consumption by young-of-the-year Baltic Sea herring Clupea harengus: a test of predictions from a bioenergetics model. Mar Ecol Prog Ser 110:145-149

Bartell SM, Breck JE, Gardner RH, Brenkert AL (1986) Individual parameter perturbation and error analysis of fish bioenergetics models. Can J Fish Aquat Sci 43:160-168

Bartsch J, Coombs SH (2004) An individual-based model of the early life history of mackerel (Scomber scombrus) in the eastern North Atlantic, simulating transport, growth and mortality. Fish Oceanogr 13:365-379

Baumann H, Gröhsler T, Kornilovs G, Makarchouk A, Feldmann V, Temming A (2006) Temperature-induced regional and temporal growth differences in Baltic young-ofthe-year sprat Sprattus sprattus. Mar Ecol Prog Ser 317: 225-236

Besiktepe S, Dam HG (2002) Coupling of ingestion and defecation as a function of diet in the calanoid copepod Acartia tonsa. Mar Ecol Prog Ser 229:151-164

Beyer JE, Laurence GC (1980) A stochastic model of larval growth. Ecol Model 8:109-132

Blaxter JHS (1962) Herring rearing. IV. Rearing beyond the yolk-sac stage. Mar Res 1:1-18

Blaxter JHS (1965) The feeding of herring larvae and their ecology in relation to feeding. CALCOFI (Calif Coop Ocean Fish Investig) Rep 10:79-88

Bochdansky AB, Deibel D (2001) Consequences of model specification for the determination of gut evacuation rates: redefining the linear model. Can J Fish Aquat Sci 58: 1032-1042

Bochdansky AB, Brunemeyer ND, Leggett WC (2006) Model evaluation of linear gut evacuation in the larval radiated shanny using a combination of laboratory and field data. Trans Am Fish Soc 135:390-398

Boehlert GW, Yoklavich MM (1983) Effects of temperature, ration, and fish size on growth of juvenile black rockfish, Sebastes melanops. Environ Biol Fish 8:17-28

Boehlert GW, Yoklavich MM (1984) Carbon assimilation as a function of ingestion rate in larval Pacific herring, Clupea harengus pallasi Valenciennes. J Exp Mar Biol Ecol 79: 251-262

Broekhuizen N, Parkyn S, Miller D, Rose R (2002) The relationship between food density and short term assimilation rates in Potamopyrgus antipodarum and Deleatidium sp. Hydrobiologia 477:181-188

Broughton EA, Lough RG (2006) A direct comparison of MOCNESS and Video Plankton Recorder zooplankton abundance estimates: possible applications for augment- ing net sampling with video systems. Deep-Sea Res II 53:2789-2807

Buckley LJ, Dillman DW (1982) Nitrogen utilization by larval summer flounder, Paralichthys dentatus (Linnaeus). J Exp Mar Biol Ecol 59:243-256

Canino MF, Bailey KM (1995) Gut evacuation of walleye pollock larvae in response to feeding conditions. J Fish Biol 46:389-403

Chiba K (1961) The basic study on the production of fish seedling under possible control. I. The effect of food in quality and quantity on the survival and growth of common carp fry. Tansuiku Suisan Kenkyusho Kenkyu Hokoku 11:105-132

Chitty N (1981) Behavioral observations of feeding larvae of bay anchovy, Anchoa mitchilli, and bigeye anchovy, Anchoa lamprotaenia. Rapp P-V Reun Cons Int Explor Mer 178:320-321

Corazza L, Nickum JG (1983) Rates of food passage through the intestinal tract of fingerling walleyes. Prog Fish Cult 45:183-184

Dagg MJ, Waker EW Jr (1978) Ingestion, gut passage, and egestion by the copepod Neocalanus plumchrus in the laboratory and in the subarctic Pacific Ocean. Limnol Oceanogr 32:178-188

Dekshenieks MM, Donaghay PL, Sullivan JM, Rines JEB, Osborn TR, Twardowski MS (2001) Temporal and spatial occurrence of thin phytoplankton layers in relation to physical processes. Mar Ecol Prog Ser 223:61-71

Dickmann M (2006) Feeding ecology of sprat (Sprattus sprattus L.) and sardine (Sardine pilchardus W.) larvae in the Baltic Sea and in the North Sea. PhD thesis, Institute für Ostseeforschung, University of Rostock

Doohan M (1973) An energy budget for adult Brachionus plicatilis Muller (Rotatoria). Oecologia 13:351-362

Elliott JM (1976) Energy losses in the waste products of brown trout (Salmo trutta L.). J Anim Ecol 45:561-580

Fiksen Ø, Folkvord A (1999) Modelling growth and ingestion processes in herring Clupea harengus larvae. Mar Ecol Prog Ser 184:273-289

Fossum P (1983) Digestion rate of food particles in the gut of larval herring (Clupea harengus L.). Fiskdir Skr Serie Havundersokelser 17:347-357

Gelman A, Kuz'mina V, Drabkin V, Glatman L (2003) Temperature dependent characteristics of intestinal glycyl-Lleucine dipeptidase in boreal zone fish. Comp Biochem Physiol B 136:323-329

Govoni JJ, Peters DS, Merriner JV (1982) Carbon assimilation during the larval development of the marine teleost Leiostomus xanthurus Lacepede. J Exp Mar Biol Ecol 64:287-299

Govoni JJ, Boehlert GH, Watanabe T (1986) The physiology of digestion in fish larvae. Environ Biol Fish 16:59-77

Herrera G, Balbontín F (1983) Tasa de evacuacion intestinal e incidencia de alimentacion en larvas de Sardinops sagax musica (Pisces, Clupeiformes). Rev Biol Mar Valparaíso 19:113-132

Hinrichsen HH, Möllmann C, Voss R, Köster FW, Kornilovs G (2002) Biophysical modeling of larval Baltic cod (Gadus morhua) growth and survival. Can J Fish Aquat Sci 59: 1858-1873

Houde ED (1989) Comparative growth, mortality, and energetics of marine fish larvae: temperature and implied latitudinal effects. Fish Bull 87:471-475

Houde ED, Schekter RC (1983) Oxygen uptake and comparative energetics among eggs and larvae of three subtropical marine fishes. Mar Biol 72:283-293

Houde ED, Zastrow CE (1993) Ecosystem and taxon-specific 
dynamic and energetics properties of larval fish assemblages. Bull Mar Sci 53:290-335

Huwer B (2004) Larval growth of Sardina pilchardus and Sprattus sprattus in relation to frontal systems in the German Bight. Diplomarbeit, Christian-Albrechts-Universität, Kiel

Johnston TA, Mathias JA (1996) Gut evacuation and absorption efficiency of walleye larvae. J Fish Biol 49:375-389

Karjalainen J, Koho J, Viljanen M (1991) The gastric evacuation rate of vendace (Coregonus albula L.) larvae predating on zooplankters in the laboratory. Aquaculture 96: 343-351

Kiørboe T, Munk P, Richardson K (1987) Respiration and growth of larval herring Clupea harengus: relation between specific dynamic action and growth efficiency. Mar Ecol Prog Ser 40:1-10

Lankford Jr TE, Targett TE (1997) Selective predation by juvenile weakfish: post-consumptive constraints on energy maximization and growth. Ecology 78:1049-1061

Laurence GC (1971) Digestion rate of larval largemouth bass. NY Fish Game J 18:52-56

Laurence GC (1985) A report on the development of stochastic models of food limited growth and survival of cod and haddock larvae. In: Laurence GC, Lough RG (eds) Growth and survival of larval fishes in relation to the trophodynamics of Georges Bank cod and haddock. NOAA Tech Memo NMFS 36:83-150

Letcher BH, Rice JA, Crowder LB, Rose KA (1996) Variability in survival of larval fish: disentangling components with a generalized individual-based model. Can J Fish Aquat Sci 53:787-801

Lough RG, Buckley LJ, Werner FE, Quinlan JA, Edwards KP (2005) A general biophysical model of larval cod (Gadus morhua) growth applied to populations on Georges Bank. Fish Oceanogr 14:241-262

Lough RG, Broughton EA, Buckley LJ, Incze LS, Pehrson Edwards $\mathrm{K}$, Converse $\mathrm{R}$, Aretxabaleta A, Werner FE (2006) Modeling growth of Atlantic cod larvae on the southern flank of Georges Bank in the tidal-front circulation during May 1999. Deep-Sea Res II 2771-2788

MacKenzie BR, Leggett WC, Peters RH (1990) Estimating larval fish ingestion rates: can laboratory derived values be reliably extrapolated to the wild? Mar Ecol Prog Ser 67:209-225

Maes J, Limburg KE, van de Putte A, Ollevier F (2005) A spatially explicit, individual-based model to assess the role of estuarine nurseries in the early life history of North Sea herring, Clupea harengus. Fish Oceanogr 14:17-31

Mills EL, Ready RC, Jahncke M, Hanger CR, Trowbridge C (1984) A gastric evacuation model for young yellow perch, Perca flavescens. Can J Fish Aquat Sci 41:513-518

Munk P (1992) Foraging behaviour and prey size spectra of larval herring Clupea harengus. Mar Ecol Prog Ser 80: $149-158$

Munk P (1993) Differential growth of larval sprat Sprattus sprattus across a tidal front in the eastern North Sea. Mar Ecol Prog Ser 99:17-27

Munk P (1995) Foraging behaviour of larval cod (Gadus morhua) influenced by prey density and hunger. Mar Biol 122:205-212

Munk R, Kiørboe T (1985) Feeding behaviour and swimming activity of larval herring (Clupea harengus L.) in relation to density of copepod nauplii. Mar Ecol Prog Ser 24:15-21

Noble RL (1973) Evacuation rates of young yellow perch, Perca flavescens (Mitchill). Trans Am Fish Soc 102:
$759-763$

Owen RW (1989) Microscale and finescale variations of small plankton in coastal and pelagic environments. J Mar Res 47:197-240

Peck MA, Clemmesen C, Herrmann JP (2005) Ontogenic changes in the allometric scaling of the mass and length relationship in Sprattus sprattus. J Fish Biol 66:882-887

Pedersen BH (1984) The intestinal evacuation rates of larval herring (Clupea harengus L.) predating on wild plankton. Dana 3:21-30

Pedersen BH, Hjelmeland K (1988) Fate of trypsin and assimilation efficiency in larval herring (Clupea harengus) following digestion of copepods. Mar Biol 97:467-476

Pepin P, Penney R (2000) Feeding by a larval fish community: impact on zooplankton. Mar Ecol Prog Ser 204:199-212

Peters DS, Kjelson MA (1975) Consumption and utilization of food by various postlarval and juvenile fishes of North Carolina estuaries. Estuar Res 1:448-472

Pitchford JW, James A, Brindley JA (2003) Optimal foraging in patchy turbulent environments. Mar Ecol Prog Ser 256: 99-110

Pitchford JW, James A, Brindley JA (2005) Quantifying the effects of individual and environmental variability in fish recruitment. Fish Oceanogr 14:156-160

Ré P, Gonçalves E (1993) Growth of sprat Sprattus sprattus larvae in the German Bight (North Sea) as inferred from otolith microstructure. Mar Ecol Prog Ser 96:139-145

Ryer CH, Boehlert GW (1983) Feeding chronology, daily ration, and the effects of temperature upon gastric evacuation in the pipefish (Syngnathus fuscus). Environ Biol Fish 9: 301-306

Shepherd WC, Mills EL (1996) Diel feeding, daily food intake, and Daphnia consumption by age-0 gizzard shad in Oneida Lake, New York. Trans Am Fish Soc 125:411-421

Talbot C, Higgins PJ, Shanks AM (1984) Effects of pre- and post-prandial starvation on meal size and evacuation rate of juvenile Atlantic salmon, Salmo salar L. J Fish Biol 25: $551-560$

Tilseth S, Ellertsen B (1984) Food consumption rate and gut evacuation processes of first feeding cod larvae (Gadus morhua L.). Flödevigen Rapp 1:167-182

Walton WE, Hairston NG, Wetterer JK (1992) Growth-related constraints on diet selection by sunfish. Ecology 73: 429-437

Werner F, Perry RI, Lough RG, Naimie CE (1996) Trophodynamic and advective influences on Georges Bank larval cod and haddock. Deep-Sea Res II 43:1793-1822

Werner RG, Blaxter JHS (1980) Growth and survival of larval herring (Clupea harengus) in relation to prey density. Can J Fish Aquat Sci 37:1063-1069

Worischka S, Mehner T (1998) Comparison of field-based and direct estimates of daily food consumption in larval perch and zander. J Fish Biol 53:1050-1059

Xu Y, Wang WX (2001) Individual responses of trace-element assimilation and physiological turnover by the marine copepod Calanus sinicus to changes in food quantity. Mar Ecol Prog Ser 218:227-238

Young JW, Davis TLO (1990) Feeding ecology of larvae of southern bluefin, albacore and skipjack tunas (Pisces: Scombridae) in the eastern Indian Ocean. Mar Ecol Prog Ser 61:17-29

Young JW, Davis TLO (1992) Feeding ecology and interannual variations in diet of larval jack mackerel, Trachurus declivis (Pisces: Carangidae), from coastal waters of eastern Tasmania. Mar Biol 113:11-20

Submitted: August 2, 2006; Accepted: March 1, 2007

Proofs received from author(s): September 17, 2007 